\title{
Life-history traits of the symbiotic scale-worm Branchipolynoe seepensis and its relationships with host mussels of the genus Bathymodiolus from hydrothermal vents
}

\author{
Temir A. Britayev', Daniel Martin², Elena M. Krylova ${ }^{3}$, Rudo von $\operatorname{Cosel}^{4}$, Tatiana S. \\ Aksiuk $^{1}$ \\ ${ }^{1}$ A.N. Severtzov Institute of Ecology and Evolution (RAS), Moscow, Russia. \\ ${ }^{2}$ Centre d'Estudis Avançats de Blanes (CSIC), Blanes (Girona), Catalunya (Spain). \\ ${ }^{3}$ P.P. Shirshov Institute of Oceanology (RAS), Moscow, Russia. \\ ${ }^{4}$ Museum National d'Histoire Naturelle, Paris, France.
}

\section{Correspondence}

Temir A. Britayev, A.N. Severtzov Institute of Ecology and Evolution (RAS), Leninsky pr. 33, 117071 Moscow, Russia

E-mail temir@invert.sevin.msk.ru

Running title

Symbiosis of Branchipolynoe with Bathymodiolus

Keywords

Symbiosis; Host/symbiont interactions; Polychaeta; Polynoidae; Mytilidae; Hydrothermal vents.

\begin{abstract}
Associations between scale-worms and giant mussels are common constituents of hydrothermal vent and cold seep ecosystems, but very little is known about their nature and ecology. Here, we analyze the ecological characteristics of the associations between Branchipolynoe seepensis, an obligate symbiotic polychaete, and their host mytilid mussels Bathymodiolus puteoserpentis and B. azoricus inhabiting hydrothermal vent fields on the Mid-Atlantic Ridge. Infested mussels generally harbored a single symbiont $(<4 \%$ had $2-6$ worms). Infestation rate varied from $7.2 \%$ to $76.5 \%$, increasing with mussel size and was significantly lower for B. puteoserpentis.
\end{abstract}


Symbiont density ranged between 1071-1191 ind. $\mathrm{m}^{-2}$. Female symbiont size was always positively correlated with host size, while only males and juveniles from small mussels showed the same trend. This suggested a relatively long-lasting host/symbiont association for females and short-lasting association with successive reproductive migrations for adult males. The sex ratio of symbionts was always biased in favor of females. Males were smaller and more slender than females and had one mode in their size distributions, whereas females typically had three or more modes, suggestive of a longer life span in females. Between 59.1 and $72.2 \%$ of mussels had damaged soft tissues with substantially higher incidence of trauma in infested ones, suggesting that symbionts may cause traumas. The symbionts also induce tunnel-like structures among the ctenidia, indicating fidelity to a particular location inside the host. Based on our data, together with the fact that infested mussels became relatively wider than non-infested ones, this association is considered parasitic (likely kleptoparasitic). Our data, together with those from previous studies, allowed us to define the main life history traits of B. seepensis: 1) the relationship with their host is parasitic, 2) the association begins at the smallest mytilid size classes, 3) there is sexual dimorphism in body size, 4) sex ratio deviates from 1:1 in favor of females, 5) fertilization occurs through temporal pairing and pseudocopulation, 6) sperm are stored by females, 7) eggs are large (likely lecitotrophic or with direct development), 8) females have a longer life-span than males, 9) adult males may be semalparous, undertaking reproductive migrations followed by a short period of pairing and then death, and 10) females have a semicontinuous iteroparous reproductive cycle. 


\section{Problem}

The first known symbiotic polychaete at hydrothermal vents, Branchipolynoe symmyitilida, was described as new species and genus of scale-worm in the early 1980's (Pettibone 1984). Successive discoveries of new vents and seeps gave rise to new findings, and the current list includes about 20 species of symbiotic polychaetes from three families, Polynoidae, Nautiliniellidae and Phyllodocidae (Miura 1988; Desbuyères \& Segonzac 1997). Symbiotic polychaetes are nearly ubiquitous constituents of the hydrothermal vents and cold-water seep site communities, where they are harbored by vestimentiferans, mytilids (i.e. Bathymodiolus spp.), vesicomyids (i.e. Calyptogena spp.) and some species of solemyids and thyasirids (Desbuyères \& Segonzac 1997; Gebruk 2002). Nevertheless, their life cycle, population ecology, infestation characteristics, and relationships with the hosts, as well as their role in the communities, remain virtually unknown.

Recent detailed studies on Branchipolynoe seepensis Pettibone, 1986 revealed several surprising features, very rare or unusual among scale-worms. These include external sexual dimorphism, a sex ratio biased in favor of females, extremely large eggs up to $400 \mu \mathrm{m}$ in diameter (indicating either lecithotrophic larvae or direct development), a genital tract storing both mature oocytes and sperm, and internal fertilization by pseudocopulation (Van Dover et al. 1999; Jollivet et al. 2000). Protandrous hermaphroditism was rejected as a feasible explanation of female-biased sex ratio and sexual size dimorphisms in B. seepensis (Van Dover et al. 1999; Jollivet et al. 2000), while a differential mortality between sexes was proposed as the only viable explanation (Jollivet et al. 2000). In B. seepensis, females showed a positive size relationship with their mytilid host Bathymodiolus azoricus, which was not detected for males and juveniles presumably as an indication of their mobility and absence of size-segregation behavior during the infestation process (Jollivet et al. 2000). The symbiosis between B. seepensis and B. azoricus from the Mid-Atlantic vent field Lucky Strike is among the best-studied associations involving hydrothermal invertebrates, and is therefore an excellent model for further investigations.

Host/symbiont relationships among vent invertebrates have only been studied in a few associations. For instance, the presence of fastening hook-like chaetae led scientists to consider nautiliniellid polychaetes associated with bivalves (vesicomyids and solemyids) as parasites (Martin \& Britayev 1998). The species of Branchipolynoe associated to Bathymodiolus spp. have 
usually been regarded as commensals (Pettibone 1984; 1986; Van Dover et al. 1999), with the analyses of stable carbon isotopes strongly supporting either a close nutritional connection between B. symmytilida and its host mussels from the Galapagos Rift (Fisher et al. 1994), or a consumer-diet relationship between an undescribed Branchipolynoe species and its host Bathymodiolus aff. brevior at the Kaieri hydrothermal vent field in the Indian Ocean (Van Dover 2002). Fisher et al. (1994) assumed that the polychaetes feed on bacteria-laden mucus and pseudofaeces from the host mussels and/or graze on free-living bacteria, as no visible lesions were found in the soft tissues of the infested mussels. Alternatively, pseudofaeces and gill bits were found in the gut of B. symmitilida (Desbruyères et al. 1985), and physical traumas on gill filaments were observed in specimens of Bathymodiolus spp. infested by B. seepensis (Ward et al. 2004), suggesting a parasitic behavior. Our preliminary results demonstrated a trophic link between B. seepensis and Bathymodiolus azoricus based on analyses of the symbionts' position in the mantle cavity of the host mussels, intestinale contents, and a negative effect on mussel growth associated with the presence of symbionts in the Mid Atlantic vent field Lucky Strike (Britayev et al., 2003).

In this study, we used material collected by French and Russian expeditions to the MidAtlantic Ridge to provide a more complete picture of the life cycle of Branchipolynoe seepensis as a symbiont of the giant hydrothermal vent mytilids Bathymodiolus puteoserpentis (Logatchev and Snake Pit) and B. azoricus (Rainbow and Lucky Strike). Specifically, we focused on the analyses of both the infestation patterns and the peculiarities of the symbiont life cycle including size structure, sexual dimorphism, and reproductive traits, in order to assess the nature of the host/symbiont relationships.

\section{Material and Methods}

Samples were collected during the expeditions of the research vessels Akademik Mstislav Keldysh (Russia) and Nadir (France) to the Mid-Atlantic Ridge hydrothermal vents. The Russian expeditions visited Logachev (1998), Snake Pit (2002), Lucky Strike (2002) and Rainbow (1999, 2002) vents, and the French expeditions visited Lucky Strike (1993, 1995). Specimens of

mytilids Bathymodiolus puteoserpentis and B. azoricus were collected from the manned 
submersibles "Mir" and "Nautile", with the help of manipulator arms, and transported to the surface inside insulated baskets. The mollusks were fixed with 3-10\% neutral formalin and stored in $70 \%$ alcohol.

Once collected, the mollusk length, width and height were measured.Shells were then opened and the number of symbiotic polychaetes and any modifications in the morphology of the host soft tissues were quantified. The polychaetes were carefully extracted under a binocular microscope, sexed according to the number of nephridial papillae (two pairs in females, one pair in males), measured (maximum antero-posterior length) and checked for various types of traumas. A chi-square test was used to assess the significance of the deviation from the 1:1 sex ratio within the populations studied. Total worm length was used for demographic analyses, as virtually all worms were intact. Length was correlated with wet weight (Jollivet et al. 2000) and with width in both studied populations (Fig. 1). To avoid possible bias due to the largest of females, lengths and widths were standardized by dividing each data series by the largest value (Fig. 1). The number of specimens used for each approach depended on the availability of adequate material. The sample sizes have been indicated either in the figures or in the text.

Mussel densities were calculated for the Lucky Strike 2002 sampling based on two different methods. First, the whole mussel individuals attached to a $0.21 \mathrm{~m}^{2}$ boulder were detached and counted. Second, two squares $(0.2 \times 0.2 \mathrm{~m})$ were randomly selected on a photo of the studied mussel bed and the amount of mussels in each square was counted. Then densities were estimated as mussels per $\mathrm{m}^{2}$ in order to provide density range for the area.

Size-frequencies were decomposed using the Bhattacharya's (1967) method and the simplex algorithm of the NORMSEP routine in the FISAT II package, version 1.0.2. (Gayanilo et al. 1997). This method assumed that Branchipolynoe seepensis size distribution followed a withincohort Gaussian distribution. The assumptions of this method differ from those of other methods of modal decomposition in than an assessment of mode number and approximate position in the size histogram are not required (Ivanov \& Stolyarenko, 1996), and raw data are used directly instead of smoothing with a weighted moving average (Pauly \& David 1981).

Regression analyses were used to estimate the width / length relationships for symbionts and the size relationships between hosts and symbionts of different sexes. Differences in the slope for the width/length relationship between male and female symbionts were assessed by analysis of covariance (ANCOVA). Depending on the type of the association, the presence of symbionts 
may affect the metabolism of the host and, thus, their normal growth (Bierbaum \& Ferson 1986). As we hypothesized that the analysis of the relationships between shell width and length in infested and non-infested hosts may reveal the postulated existence of such an influence in Bathymodiolus azoricus, we also used regression and ANCOVA analyses to examine these relationships. One-way analysis of variance (ANOVA) was used to test for differences in the incidence of traumas in infested and non-infested host mollusks. Student's t-test was used to analyze the differences in infestation rate between the two host species. Two-way ANOVA was used to assess the differences in size, using sample location and symbiont sex as factors. The factors responsible for the observed differences were analyzed by Tukey HSD post-hoc test.

When required, data were rank-transformed in order to meet the assumptions of normality and homoscedasticity required for parametric analyses (Zar 1984). All analyses were carried out using the SYSTAT 5 (vers. 5.2.1, copyright SYSTAT inc., 1990-92) statistical package. The differences between observed and expected frequencies both for sexes and age groups were performed with the help of the PAIRS-GENERATOR software (Lyskin 2003), based on worms from all collected samples of Bathymodiolus azoricus.

\section{Results}

\section{Infestation characteristics}

\section{Infestation rate, abundance and intensity}

Three hundred specimens Bathymodiolus puteoserpentis and 680 specimens of B. azoricus were analyzed. The two species harbored 41 and 400 specimens of Branchipolynoe seepensis, respectively, with the smallest infested individual being a $3.6 \mathrm{~mm}$ long $B$. puteoserpentis from Logatchev, 1998). The infestation rate varied from $7.1 \%$ to $76.5 \%$ and was lower $(\mathrm{t}=-4.3, \mathrm{p}<$ 0.02) for B. puteoserpentis (Table 1). However, symbionts were more prevalent in the larger mytilids (Fig. 2). In B. azoricus, this only occurred in small mytilids (less than 40-60 mm in length), both in 1995 and 2002 (Fig. 2A, B). Although less clear (probably due to the lower number of individuals), a similar trend occurred in the Rainbow vent (Fig. 2C). The abundance 
ranged from 0.07 to 0.8 symbionts per host and was lower $(\mathrm{t}=-8.6, \mathrm{p}<0.007)$ for $B$. puteoserpentis (Table 1). Each infested host harbored from 1 to 6 worms, but multiple infestations were very rare and the presence of a single symbiont dominated (Table 2). Thus, $B$. seepensis showed a characteristic regular pattern inside both mytilid hosts.

Worms density was calculated taking into account the density of mussels, their size range and infestation. Mussel density estimates ranged from 1458 ind. $\mathrm{m}^{-2}$ (378 individuals in $0.21 \mathrm{~m}^{2}$ boulder) and $1700-1890$ ind. $\mathrm{m}^{-2}$ (from the squares in photos). In the first case, infestation rates were calculated directly $(80.9 \%, \mathrm{~N}=21)$, this leading to an estimate of symbionts density of 1179.5 ind. $\mathrm{m}^{-2}$. In the second case, mussel densities were slightly underestimated, as some small mussels were covered by larger ones in the images. However, taking into account that counted mussels were 45 to $75 \mathrm{~mm}$ long, with minimum infestation rates of $63 \%$ (up to 100\%, Fig. 2B), worm densities may range between 1071 and 1191 ind. $\mathrm{m}^{-2}$. Both estimates were thus very similar, and likely represents lower abundances than the maximum expected in the native habitats.

\section{Host traumas}

Most Bathymodiolus azoricus specimens (72.2\% from Lucky Strike in 1995 and 59.1\% in 2002) showed damaged soft tissues: truncation of ctenidia, shortening or elimination of labial palps (Fig. 3) and deformation of the foot (i.e. size reduction and modification of proportions).

In 1995, the incidence of traumas was about 5 times higher in infested than in non-infested mollusks (Fig. 4A). Among infested hosts, palps were most frequently traumatized, followed by ctenidia (Fig. 4B). Ctenidia damage was most common in the anterior parts of demibranchs. The incidence of trauma on the foot was rare and similar in infested and non-infested mollusks. The incidence of trauma was higher when female symbionts were present, particularly on palps.

In 60 hosts, most of them infested (Fig. 4A), the symbionts (either juveniles, males or females) were found inside a tunnel-like structure formed by the ctenidial lamellae between demibranches or with their bodies outlined by an epithelial ridge or callosity that originated from the mollusk mantle. Remains of this structure were also present, although nearly three times less frequent, in non-infested hosts (Fig. 4A).

A substantial difference between infested and non-infested specimens was also observed in 2002 , with four times more traumas in the former $(78.8 \%, \mathrm{~N}=85$ and $19.0 \%, \mathrm{~N}=42$, 
respectively). Among infested hosts, traumas was most frequent on palps $(72.9 \%)$, then on ctenidia (35.3\%). Only two mytilids harbored the symbionts inside tunnel-like structures between demibranchs.

\section{Host/symbiont size-relationships}

Significant positive linear size-regressions between Branchipolynoe seepensis (Br) and Bathymodiolus azoricus (Ba) from Lucky Strike 1995 were observed for all symbiont stages (Fig. 5 , solid lines). The percentage of variability explained was low for juveniles $(<30 \%, \mathrm{Br}=0.074$ $\left.\mathrm{Ba}+2.170, \mathrm{r}^{2}=0.26, \mathrm{p}<0.01\right)$, intermediate for males $\left(>50 \%, \mathrm{Br}=0.236 \mathrm{Ba}+3.050, \mathrm{r}^{2}=0.56\right.$, $\mathrm{p}<0.00001)$ and very high for females $\left(>85 \%, \mathrm{Br}=0.304 \mathrm{Ba}+1.072, \mathrm{r}^{2}=0.87, \mathrm{p}<0.000001\right)$. In 2002, only B. seepensis females showed a positive linear regression $\left(\mathrm{Br}=0.197 \mathrm{Ba}+9.707, \mathrm{r}^{2}\right.$ $=0.40, \mathrm{p}<0.001)($ Fig. 5). This different pattern was related to differences in mytilid size among samples. In 1995, B. azoricus length rarely exceeded $50 \mathrm{~mm}$, while the majority of mytilids collected in 2002 ranged from 50 to $125 \mathrm{~mm}$ long.

Pooled together, the two samples covered the whole range of mytilid sizes (Fig. 5A-C). Strong positive relationships between host and symbiont size occurred for all females. Slightly positive size-relationships occurred for males and juveniles from mytilids up to $50 \mathrm{~mm}$ and $35 \mathrm{~mm}$ long, respectively, whilst size relationships were non-significant for males and juveniles from mytilids between $50-125 \mathrm{~mm}$ and larger than $35 \mathrm{~mm}$ long, respectively. Females from Rainbow also showed a significant positive size relationship with their hosts (Fig. 5D), while the scarcity of both juveniles and males prevented any statistical treatment.

In Lucky Strike 1995, shells were significantly wider than longer in infested than in noninfested mollusks (ANCOVA, $F=7.05, \mathrm{p}=0.008$ ), while the differences were non-significant in 2002 (ANCOVA, F = 1.19, p > 0.2), likely because the low number of large non infested mollusks (Fig. 6).

\section{Sex ratio and size structure in Branchipolynoe seepensis}


Male/female ratio in Branchipolynoe seepensis deviated significantly from the expected 1:1 proportion in favor of females in all samples and sites (Lucky Strike 1995 - 49/100; Lucky Strike $2002-11 / 58$; Rainbow $2002-6 / 18$; Chi-square $=27.34, \mathrm{~F}=18.87$; $\mathrm{DF}=2, \mathrm{p}<0.01)$. The biass in sex ratio shifted with symbiont size. Males were more abundant among the small mussel size classes, then decreased with the increasing size and disappeared in the largest size classes (Fig. 7).

When present, symbiont pairs mainly consisted of female/juvenile and male/female (Fig. 8). The proportion of observed pairs significantly differed from the randomly expected $(\mathrm{t}=2.47, \mathrm{p}=$ 0.069), the former tending to be more numerous than the later for female/juvenile and male/female and vice versa for female/female.

Width was positively correlated to length for juvenile, male and female Branchipolynoe seepensis (Fig. 1). However, males tended to be significantly more slender (ANCOVA, F = 1181.5, $\mathrm{p}<0.000001$ ) than females (Fig. 1). Body length varied from sample to sample, ranging from 1 to $44 \mathrm{~mm}$ (Table 3). There was a significant combined effect of both sample and sex on size differences (Two way ANOVA, F-ratio $=6.47, \mathrm{p}<0.002$ ). Males were significantly smaller than females (Tukey HSD, p <0.00002) in all samples except Rainbow 2002, where the number of males was too low for statistical analysis. On the other hand, female sizes always differed significantly between samples (Tukey HSD, $\mathrm{p}<0.003$ ), while male sizes did not. This is expected from the significant positive regression between female and host lengths (Fig. 5) and from the dominance of large mytilids in Lucky Strike 2002 and Rainbow 2002 and of small ones in Lucky Strike 1995.

Size-frequency distributions tended to be polymodal with one mode in males and 3 - 4 in females in Lucky Strike 1995 and 2002, respectively (Fig. 9 A-B). The number of individuals was too low to analyze for the Rainbow 2002 sample.The first male and female modes (left part of the histograms) at Lucky Strike nearly coincided, with the male mode being slightly higher than the female mode (Fig. 9A-B). Males disappeared in the right part of the histograms, where females were still abundant, and had up to three additional modes (Fig. 9B). Accordingly, our populations differed from those previously reported (see Jollivet et al. 2000) in having between one mode for males (two modes were reported by Jollivet et al., 2000) and up to and four modes for females. 


\section{Presence of trauma in Branchipolynoe seepensis}

Among the Branchipolynoe seepensis infesting Bathymodiolus azoricus (Lucky Strike 1995), 79 specimens (37.3\%) showed different types of external trauma. Two main types can be distinguished: small traumas (i.e. damaged elytra, cirri or parapodia, either lacking or being smaller than those of closer segments as a consequence of regeneration processes), likely attributable to intra-specific aggressive behavior (Britayev 1991; Britayev \& Zamyshliak 1996) and large traumas (i.e. posterior end or lateral sections lost, or showing traces of regeneration), likely attributable to attacks by external predators (e.g. crabs or shrimps).

The frequency of large traumas among the symbionts was very low and similar to those affecting the parapodia. Traumas on cirri occurred at intermediate frequencies and elytra were the most frequentl structures affected (Fig. 10). Additionally, a remarkable high percentage of traumas affecting cirri occurred in juvenile worms (Fig. 10). These data, together with the regular distribution pattern of the symbionts, strongly supports the existence of intra-specific interactions and territorial behavior in Branchipolynoe seepensis.

\section{Discussion}

\section{Characteristics of the infestation}

The infestation by Branchipolynoe seepensis varied substantially among mytilids from different hydrothermal fields and sites, depending on host species and size. For instance, Bathymodiolus azoricus was significantly more infested than B. puteoserpentis. According to our data, however, this seems to be more likely related to local environmental differences than to any biological peculiarity of these species as hosts. The estimated symbionts density (i.e. $1071-1191$ ind. $\mathrm{m}^{-2}$ ), even underestimated, is comparable with the highest reported to date for any free-living scaleworm (i.e. 800 to 1300 ind. $\mathrm{m}^{-2}$ for Antinoella sarsi in Sarvala 1971), and is also very high even for an inhabitant of the densely populated vent communities. 
The infestation by Branchipolynoe seepensis may vary within a given mytilid population among different zones separated only by a few meters. However, it usually tends to be higher in larger than in smaller hosts, as is common in many other symbiotic polychaetes (Martin \& Britayev 1998). In spite of this, small mytilids are also regularly infested, which is a very rare trend for a symbiotic association and may be related to the suggested continuous reproduction and settlement of these symbionts (Jollivet et al. 2000).

The infestation intensity may reach up to six symbionts per host (Jollivet et al. 2000; our samples). However, most hosts harbored only one Branchipolynoe seepensis. Regular distributions such as this usually result from intra-specific antagonistic behavior related to territorial defense of the host (Palmer 1968; Dimock 1974; Britayev \& Smurov 1985). The existence of such antagonistic behavior in B. seepensis is indirectly supported by the presence of trauma to the parapodia and other appendages that are similar to those reported for the intraspecifically aggressive shallow-water symbiotic scale-worms Arctonoe vittata and Gastrolepidia clavigera (Britayev \& Smurov 1985; Britayev \& Zamyshliak 1996).

\section{Symbiont/host relationships: commensalisms or parasitism?}

Stable carbon isotope analyses of Branchipolynoe ssp. and their mytilid hosts demonstrate a close nutritional link (Fisher et al. 1994; Van Dover 2002). Our previous observations on the $B$. seepensis intestinal contents and predominant orientation inside the host (i.e. head-to-siphon and head-to-mouth) suggested that symbionts may consume either the filtered agglutinated suspended particles that are transported toward the host mouth, or the suspended organic particles that are transported to the siphon opening (Britayev et al. 2003). Therefore, the behavior of symbionts may be classified as kleptoparasitic (stealing food from the host rather than feeding on the host itself). Similar kleptoparasitic behavior has been reported for other symbiotic invertebrates including the polychaetes Branchiosyllis exilis, a symbiont of the brittle star Ophiocoma echinata (Hendler \& Meyer 1982); Haplosyllis villogorgicola, an associate of the gorgonian Villogorgia bebrycoides (Martin et al. 2002); the nemertean Malacobdella grossa, associated with bivalves (Gibson \& Jennings 1969); and the gastropod Trichotropis cancellata, a symbiont of the tubeworm Serpula columbiana (Iyengar 2002). 
The only previous report of Branchipolynoe trophic preferences is the finding of pseudofaeces and bits of mytilid demibranches in the gut of B. symmitilida associated with Bathymodiolus thermophilus (Desbruyères et al. 1985). In contrast, neither fragments of host tissues nor pseudofaeces occurred in the intestine of B. seepensis (Britayev et al. 2003). This difference is likely related to intraspecific differences in trophic preferences within the genus and, thus, supports the possible existence of different host/symbiont relationships among similar associations.

The idea that Branchipolynoe seepensis has a negative influence on their mytilid hosts is supported by the finding of damaged gill filaments in Bathymodiolus spp. infested by $B$. seepensis (Ward et al. 2004) and, indirectly, by the mytilid gill bits found in the gut of $B$. symmitilida (Desbruyères et al. 1985). Our studies (Britayev et al. 2003; present paper) demonstrate that the incidence of trauma was about 4-5 times higher in infested than in noninfested mollusks, so it may be assumed that symbionts cause the traumas on host tissues. However, according to our data, host tissues seem not to be a habitual food source for the symbionts. More feasibly, host traumas may be an accidental result of the "normal" feeding activities of these powerfully jawed symbionts. The presence of traumas apparently derived from symbiont activity in non-infested mytilids that could be attributed to polychaetes that either escaped from the host before being collected or were lost during the collection process. By stealing host food, consuming oxygen and accidentally damaging their tissues, the symbionts may have a negative influence on the host metabolism and, thus, on their growth. Among bivalves, decreasing growth rates may lead to changes in shell proportions (Bierbaum \& Ferson 1986; Zolotarev 1989). The shells of some of the studied populations of B. azoricus were proportionally wider than longer in infested mytilids relative to non-infested ones, this also corresponding to a proportional increase in width/length ratio (Britayev et al. 2003). Providing that modifications in shell shape may be caused by the inhibition of growth in infested hosts, the symbiont behavior should be more reliably considered as closer to parasitism than to commensalism. Special attention should be addressed to the tunnel-like structures induced by worms in the soft tissues of the host mussels. Symbiotic polychaetes may induce the formation of tubes or tunnel-like structures by stimulating a differential growth of the host's tissues (e.g., Zibrovius et al. 1975; Britayev 1981; Eckelbarger et al. 2005). Although these structures are usually a defensive reaction of the host to the presence of the symbiont, there is an obviously 
protective function for the worms. The presence of tunnel-like structures in the association of $B$. seepensis with B. azoricus is, however, the first example of such structures induced in the soft tissues of the host bivalves. Taking into account that the symbionts are located inside the mussel's mantle cavity, the protective role of the structures seems doubtful. However, although these structures may not be homologous among the different hosts, their formation may have exactly the same origin: a response of host's tissues induced by a consistent position of the worm.

\section{Peculiarities of the Branchipolynoe seepensis life cycle}

Female Branchipolynoe seepensis are substantially longer and relatively wider than males. Thus, in addition to a different number of gonoduct papillae, sexual dimorphism seems also to be expressed as differences in body proportions and size. Size dimorphism was previously attributed to a sexually-biased mortality (Jollivet et al. 2000), this leading to a different life-span for males and females. In fact, the polymodal size-frequency distribution of symbionts (Jollivet et al. 2000; present paper) likely indicates a periodic recruitment. The first modal groups (Fig. 9) likely represent the same cohort both for males and females. However, females have two or three additional modes and large animals belonging to an older cohort were not rare (Fig. 9). These differences in cohort number between males and female's resemble those previously reported (Jollivet et al. 2000), but our data differ in having one and four modes instead of two and three for males and females, respectively. In any case, female size frequency includes one or threemore cohorts than male's, evidencing the shorter life span of the later.

Female Branchipolynoe seepensis show a positive size-relationship with their hosts, while neither males nor juveniles showed a similar trend (our data from Lucky Strike 2002; Jollivet et al. 2000). Surprisingly, males and juveniles showed positive size-relationships with their respective hosts in our samples from Lucky Strike 1995. The origin of this discrepancy derived from the host size-range of the different data sets. The first two only included mytilids larger than $40 \mathrm{~mm}$, while the 1995 samples started at about $4 \mathrm{~mm}$ and never exceeded $45 \mathrm{~mm}$ in length. While the size of $B$. seepensis females seems to be well correlated with host size all along their respective range, similar relationships only occurred for males and juveniles living in small hosts 
(i.e., whose length does not exceed 45-50 $\mathrm{mm}$ and 30-35 mm, respectively) and never occurred for larger hosts.

Positive symbiont/host size-relationships are not common among symbiotic polychaetes (Martin, Britayev 1998) and have not yet been discussed for the association between Branchipolynoe seepensis and Bathymodiolus spp. Two hypotheses have been suggested to explain such positive relationships. First, there may be active size-segregation behavior, as as reported both for the symbiotic coral-dwelling crab Trapezia ferruginea (Adams et al. 1985) and the fish Gobiodon histrio (Hobbs \& Munday 2004), which seem to be able to migrate from colony to colony to choose one of an appropriate size. Second, there may be parallel growth of hosts and symbionts, reported both for the nemertean Malacobdella grossa, hosted by Arctica islandica (Sundet \& Jobling 1985) and the pontoniin shrimp Anchistus custos, hosted by the bivalve Pinna bicolor (Britayev \& Fahrutdinov 1994). However, we suggest a third hypothesis, that fast growth of the symbionts may also explain this pattern. In that case, the maximum size of the symbiont may be strictly limited by the host size.

Some Branchipolynoe seepensis (mainly juveniles and males) seem to be able to leave their host mollusks to infest new ones, either driven by intra-specific competition (interference) in juveniles, or by an active searching of a reproductive partner in males. However, the migration process seems not to be common, as direct observations and specific searching from the submersible "Mir" in 2002 cruise of the R/V "Mstislav Keldish" did not reveal the presence of $B$. seepensis outside their hosts (Krilova \& Gebruk, personal observations). Our data on locations and host traumas also indicate that symbiont position inside the mantle cavity usually tends to remain unchanged for a long time. In other words, $B$. seepensis spends a substantial part of its life inside the same host, even in same location, in contrast with other more mobile symbionts like the above-mentioned T. ferruginea and G. histrio. Accordingly, the second (i.e. growth in parallel) and third (i.e. fast symbiont growth) hypotheses seem more likely to explain the observed trends in host/symbiont size relationships.

The nature of the observed differences in host/symbiont size-relationships of females vs. that of males/juveniles must also be explained. The maximum male length, about $17 \mathrm{~mm}$, corresponds to a $45-50 \mathrm{~mm}$ host length, which represents the upper limit in the positive sector of male/host size-regression (Fig. 5B). Accordingly, all (or nearly all) males have to leave their hosts (or die) at, or just before, this critical size. The resulting emptied mollusks may be re-infested by 
juveniles, leading to a disruption in the host/symbiont size relationship when the scale worms become adults (Fig. 5B, right side of the graph). In the case of juveniles, the upper limit of the positive size-relationship is around $7 \mathrm{~mm}$ and $35 \mathrm{~mm}$ length for the symbionts and hosts, respectively. Larger worms have already started to develop secondary sexual features (e.g. gonoduct papillae), so that they are considered either as males or females. The associations at the right side of the graph (Fig. 5C), which are far from the levels of confidence for the positive regression line, are thus considered as the result of secondary colonization/recruitment of empty large mytilids.

The destiny of large males still remains an open question. Pair formation and pseudocopulation with internal fertilization was suggested as the more reliable reproductive behavior in this species (Van Dover et al. 1999; Jollivet et al. 2000). Coupling in Branchipolynoe seepensis is indirectly supported by the fact that the observed male/female pairs were more numerous than expected (Fig. 7D). So, we may assume that adult males leave their hosts, searching for females to reproduce. This is a critical behavior, likely leading to a high level of mortality, either before or after spawning. Mortality associated with spawning may be an intrinsic characteristic of males (males are semelparous, in contrast with the semi-continuous iteroparous females). This agrees with the ability of females to store sperm and may explain the observed deviation in sex ratio in favor of females among mature worms.

The combination of all above features allowed us to propose a life cycle scenario for Branchipolynoe seepensis. The symbiont (as larvae or as juveniles) infests mytilids all along the host size range, providing they are not already colonized (intra-specific competitive/aggressive behaviour). Most settlers infest small empty mytilids (i.e. $3.6 \mathrm{~mm}$ to $25-35 \mathrm{~mm}$ length), since they are substantially more numerous than larger ones (Comtet \& Desbruyères 1998; Krilova \& Gebruk personal observations), and virtually all larger mytilids are infested (Fig. 2). Juveniles then live permanently inside the mantle cavity, growing in accordance with the host growth. As growth progresses, they become males or females. Mature males leave mytilids for pairing and then die. We assume that pairing must be temporal, taking into account the low frequency of pairs compared to other symbiotic polychaetes with pair formation (e.g. Ruff 1991; Martin et al. 1992; Britayev \& Zamyshliak 1996). In turn, females continue life as permanent residents inside the hosts. Since they are able to store sperm, it seems likely that after one coupling, females may be able to produce several generations of fertilized eggs. 
Among mytilids longer than $25-35 \mathrm{~mm}$, the infestation rate exceeds $80-100 \%$ so that they are a limited resource for symbionts looking for hosts. Empty mytilids in this size group may occur as a result of symbiont death or male reproductive migrations, but also may be hosts that have never been colonized. Then, they again became available either to be colonized as a first host by settling larvae (secondary colonizers) or to be occupied by migrating males as a temporal shelter. Although the secondary colonizers will again grow together with their hosts, the wide range of host sizes will prevent the detection of any significant host/symbiont size relationship.

As a result of both our data and the previous studies (Desbruyeres et al. 1985; Fisher et al. 1994; Jollivet et al. 2000; Van Dover 2002; Britayev et al. 2003; Ward et al. 2004), it has been possible to point out some peculiarities of the Branchipolynoe seepensis life strategy. These include the establishment of parasitic (i.e. kleptoparasitic) relationships with their hosts, the starting of the association from the smallest mytilid size classes, sexual size-dimorphism, a sex ratio deviated from 1:1 in favor of females, the occurrence of temporal pairing and pseudocopulation, the sperm storage in females, the production of large eggs (likely lecitotrophic or with direct development), a life-span longer for females than for males, the possible reproductive migrations of the adult males, a short period of pairing followed by males death (semelparity), and the contrasting semi-continuous iteroparous reproductive cycle in females.

Branchipolynoe seepensis shared some of these features with other shallow-water scale worms, particularly those that have also a symbiotic behavior (Martin \& Britayev 1998). In contrast, other characteristic traits (e.g. infestation of hosts early in their ontogeny, sperm storage, extremely large eggs) strongly suggest either the existence of phylogenetic constraints in this particular group of scale worms or the development of specific adaptations to the hydrothermal environment.

\section{Summary}

The results of the present study suggest a relatively long-lasting association for female Branchipolynoe seepensis and their hosts Bathymodiolus puteoserpentis and B. azoricus, as well as reproductive migrations for adult males (which have a shorter life span). Data and hypothesis from previous studies (Desbruyères et al. 1985; Fisher et al. 1994; Jollivet et al. 2000; Van 
Dover 2002; Ward et al. 2004) support the existence of different host/symbiont relationships among associations involving closely related species. However, the presence of suspended organic particles in the intestine (Britayev et al. 2003), the presence of host traumas (as indirect result of "normal" symbiont's feeding activities) and the modification of size proportions induced in infested shells allowed us to attribute to B. seepensis a behavior closer to parasitism (i.e. kleptoparasitism) than to commensalism. This trait, together with the frequent initiation of the association from the abundant, smallest mytilid size classes, supports a highly relevant functional role for this type of association in hydrothermal vent environments.

\section{Acknowledgements}

We are grateful to A. M. Sagalevich, V. P. Nishcheta, E. S. Chernyaev, S. V. Galkin, A. V. Gebruk and the group of technical assistance of the deep-sea submersible "Mir" for helping during sample collection. We are also grateful to M.A. Puig and A.I. Buyanovsky for the help with analyses of sex-ratio and size-frequency distributions, respectively, and to S. A. Lyskin for the help with PAIRS_GENERATOR program, to the two anonymous reviewers and, specially, to the Editors whose comments significantly improved the manuscript.. This study was supported by the Russian Foundation for Basic Research (project no. 05-04-48350).

\section{References}

Adams J., Edwards A.J., Emberton H. (1985) Sexual size dimorphism and assortive mating in the obligate coral commensal Trapezia ferruginea Latreille (Decapoda, Xanthidae). Crustaceanea, 48, 188-194.

Bhattacharya C.G. (1967) A simple method of resolution of a distribution into Gaussian components. Biometrics, 23, 115-135.

Bierbaum R.M., Ferson S.S. (1986) Do symbiotic pea crabs decrease growth rate in mussels? Biological Bulletin Marine Biological Laboratory, Woods Hole, 170, 51-61. 
Britayev T.A. (1981) Two new species of commensal polynoids (Polychaeta: Polynoidae) and bibliography on polychaetes, symbionts of Coelenterata. [In Russian]. Zoologicheski Zhurnal, 60, 817-824.

Britayev T.A. (1991) Life cycle of the symbiotic scale worm Arctonoe vittata (Polychaeta: Polynoidae). Ophelia, Suppl. 5, 305-312.

Britayev T.A., Fahrutdinov R.R. (1994) Pontoniin shrimps associated with molluscs at the coast of South Vietnam. [In Russian]. In: D.S. Pavlov, J.N. Sbikin (eds.), Hydrobionts of South Vietnam. Nauka, Moscow, 128-145.

Britayev T.A., Krylova E.M., Martin D., von Cosel R., Aksiuk T.S., Martín D. (2003) Symbiont - host interaction in the association of the scale worm Branchipolynoe aff. seepensis (Polychaeta: Polynoidae) with the hydrothermal mussel, Bathymodiolus spp. (Bivalvia: Mytilidae). InterRidge News, 12, 13-16.

Britayev T.A., Smurov A.V. (1985) The structure of a population of symbionts and related biological features, Arctonoe vittata (Polychaeta, Polynoidae) taken as an example. [In Russian]. Zhurnal obschey Biologii, 46, 355-366.

Britayev T.A., Smurov A.V., Adrianov A.V., Bazhin A.G., Rhzavsky A.V. (1989) Ecology of symbiotic Polychaete Arctonoe vittata according to the peculiarity of starfish Asterias ratbunae ecology. [In Russian]. In: V.A. Sveshnicov (ed.), Symbiosis among marine animals. A.N. Severtzov Institute, Russian Academy of Sciences, Moscow, 102-127.

Britayev T.A., Zamyshliak E.A. (1996) Association of the commensal scale worm Gastrolepidia clavigera (Polychaeta: Polynoidae) with holothurians near the coast of South Vietnam. Ophelia, 45, 175-190.

Comptet T., Desbruyères D. (1998) Population structure and recruitment in mytilid bivalves from Lucky Strike and Menez Gwen hydrothermal vent fields $\left(37^{\circ} 17^{\prime} \mathrm{N}\right.$ and $37^{\circ} 50^{\prime} \mathrm{N}$ an the MidAtlantic Ridge). Marine Ecology Progress Series, 163, 165-177.

Desbruyères D., Gaill F., Laubier L., Fouquet Y. (1985) Polychaetous annelids from Hydrothermal vent ecosystems: an ecological overview. Biological Society of Washington Bulletin, 6, 103-116.

Desbuyères D., Segonzac M. (1997) Handbook of deep-sea hydrothermal vent fauna. Éditions IFREMER, Brest.

Dimock R.V. Jr. (1974) Intraspecific aggression and the distribution of a symbiotic polychaete on 
its host. In: W.B. Vernberg (ed.), Symbiosis in the sea. University of South Carolina Press, Columbia, 29-44.

Eckelbarger K.J., Watling L., Fournier H. (2005) Reproductive biology of the deep-sea polychaete Gorgoniapolynoe caeciliae (Polynoidae), a commensal species associated with octocorals. Journal of the Marine Biological Association of the United Kingdom, 86, 14251433.

Fisher C.R., Childress J.J., Macko S.A., Brooks J.J. (1994) Nutritional interactions in Galapagos Rift hydrothermal vent communities: inferences from stable carbon and nitrogen isotope analyses. Marine Ecology Progress Series, 103, 52-53.

Gayanilo Jr. F.C., Sparre P., Pauly P. (1997) FAO/ICLARM stock assessment tools (FISAT). Reference manual. FAO computerized information series (Fisheries) No. 8. FAO, Rome.

Gebruk A.V. (2002) Biology of hydrothermal systems. KMK press, Moscow.

Gibson R., Jennings J.B. (1969) Observations on diet, feeding mechanisms, digestion and food reserves of the ectocommensal rhynchocoelan Malacobdella grossa. Journal of the Marine Biological Association of the United Kingdom, 49, 17-32.

Hendler G., Meyer D.L. (1982) An association of a polychaete, Branchiosyllis exilis, with an ophiuroid, Ophiocoma echinata, in Panama. Bulletin of Marine Science, 32, 736-744.

Hobbs J.-P.A., Munday P.L. (2004) Intraspecific competition control spatial distribution and social organisation of the coral-dwelling goby Gobiodon histrio. Marine Ecology Progress Series, 278, 253-259.

Ivanov B.G., Stolyarenko D.A. (1995) Humpy shrimp (Pandalus goniurus) from the western Bering Sea: a method of estimating the annual increment. ICES. Journal of Marine Science, 199, 310-319.

Iyengar E.V. (2002) Sneaky snails and wasted worms: kleptoparasitism by Trichotropis cancellata (Mollusca, Gastropoda) on Serpula columbiana (Annelida, Polychaeta). Marine Ecology Progress Series, 244, 153-162.

Jollivet D., Empis A., Baker M.C., Houdrez S., Comtet T., Jouin-Toulmond C., Desbruyères D., Tyler P.A. (2000) Reproductive biology, sexual dimorphism, and population structure of the deep-sea hydrothermal vent scale-worm, Branchipolynoe seepensis (Polychaeta: Polynoidae). Journal of the Marine Biological Association of the United Kingdom, 80, 55-68.

Lyskin S.A. (2003) Symbionts of the Southern Vietnamese holothurians: population ecology and 
intraspecific interactions. Ph.D. Thesis, A.N. Severtzov Institute of Ecology and Evolution, Russian Academy of Sciences.

Martin D., Britayev T.A. (1998) Symbiotic polychaetes: Review of known species. Oceanography and Marine Biology: An Annual Review, 36, 217-340.

Martin D., Núñez J., Riera R., Gil J. (2002) On the associations between Haplosyllis (Polychaeta, Syllidae) and gorgonians (Cnidaria, Octocorallaria), with a description of a new species. Biological Journal of the Linnean Society, 77, 455-477.

Martin D., Rosell D., Uriz M.J. (1992) Harmothoe hyalonemae sp. nov. (Polychaeta, Polynoidae), an exclusive inhabitant of different Atlanto-Mediterranean species of Hyalonema (Porifera, Hexactinellida). Ophelia, 35, 169-185.

Miura T. (1988) A new species of the genus Protomystides (Annelida, Polychaeta) associated with a vestimentiferan worm fom the Hatsushima cold-seep site. Proceedings of the Japanese Society of Systematics and Zoology, 38, 10-14.

Palmer J.B. (1968) An analysis of the distribution of a commensal polynoid on it hosts. Ph.D. Thesis, University of Oregon.

Pauly D., David N. (1981) ELEFAN I, a BASIC program for the objective extraction of growth parameters from length-frequency data. Helgoländer Meeresuntersuchungen, 28, 205-211.

Pettibone M.H. (1984) A new scale-worm commensal with deep-sea mussels on the Galapagos hydrothermal vent (Polychaeta: Polynoidae). Proceedings of the Biological Society of Washington, 97, 226-239.

Pettibone M.H. (1986) A new scale worm commensal with deep-sea mussels in the seep-sites at the Florida Escarpment in the Eastern Gulf of Mexico (Polychaeta: Polynoidae: Branchipolynoidae). Proceedings of the Biological Society of Washington, 99, 444-451.

Ruff R.E. (1991) A new species of Bathynoe (Polychaeta: Polynoidae) from the Northeast Pacific Ocean commensal with two species of deep-water asteroids. Ophelia, Suppl. 5, 219-230.

Sarvala J. (1971) Ecology of Harmothoe sarsi (Malmgren) (Polychaeta, Polynoidae) in the northern Baltic area. Zoologici Fennici. Annales Zoologici Fennici, 8, 231-309.

Sundet J.H., Jobling M. (1985) An investigation of the interactions between the nemertine, Malacobdella grossa, and its bivalve host, Arctica islandica. In: J.S. Gray, M.E. Christiansen (eds.), Marine Biology of Polar Regions and Effects of Stress on Marine Organisms: Proceedings of the 18th European Marine Biology Symposium, University of Oslo, Norway, 
14-20 August 1983. European Marine Biology Symposia. University of Oslo, Oslo, Norway, $185-197$.

Van Dover C.L. (2002) Trophic relationships among invertebrates at the Kairei hydrothermal vent field (Central Indian Ridge). Marine Biology, 141, 761-772.

Van Dover C.L., Trask J., Gross J., Knowlton A., Van Dover C.L. (1999) Reproductive biology of free-living and commensal polynoid polychaetes at the Lucky Strike hydrothermal vent field (Mid-Atlantic Ridge). Marine Ecology Progress Series, 181, 201-214.

Ward M.E., Shields J.D., Van Dover C.L. (2004) Parasitism in species of Bathymodiolus (Bivalvia: Mytilidae) mussels from deep-sea seep and hydrothermal vents. Diseases of Marine Organisms, 62, 1-16.

Zar J.H. (1984) Biostatistical Analysis. Prentice Hall International, New Jersey.

Zibrowius H., Southward E.C., Day J.H. (1975) New observations on a little-known species of Lumbrineris (Polychaeta) living on various Cnidarians, with notes on its recent and fossil Scleractinian hosts. Journal of the Marine Biological Association of the United Kingdom, 55, 83-108.

Zolotarev V.N. (1989) Sclerochronology of marine bivalves. Naukova dumka, Kiev. 


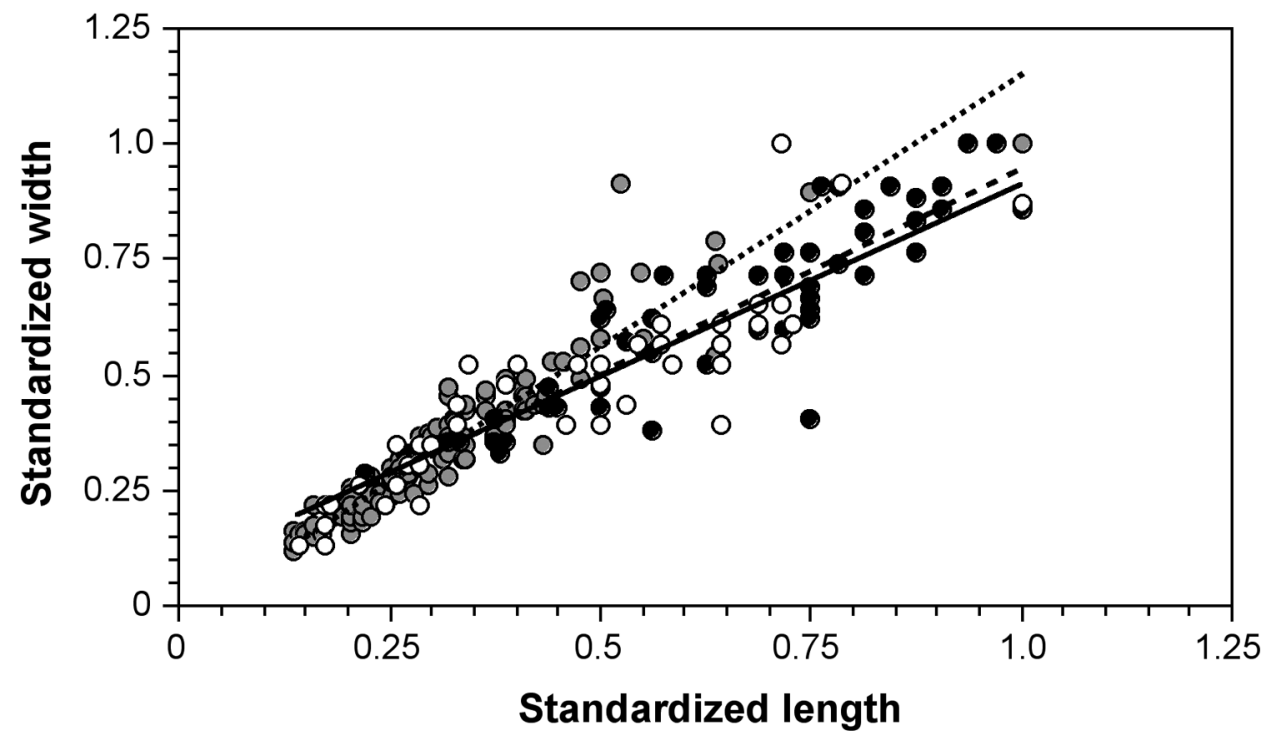
○ Juveniles
$y=0.829 x+0.075, r^{2}=0.798, p<0.00001$
- Males
- - - - $\quad y=0.880 x+0.068, r^{2}=0.796, p<0.00001$
- Females
n $\quad y=1.175 x-0.018, r^{2}=0.889, p<0.00001$ 


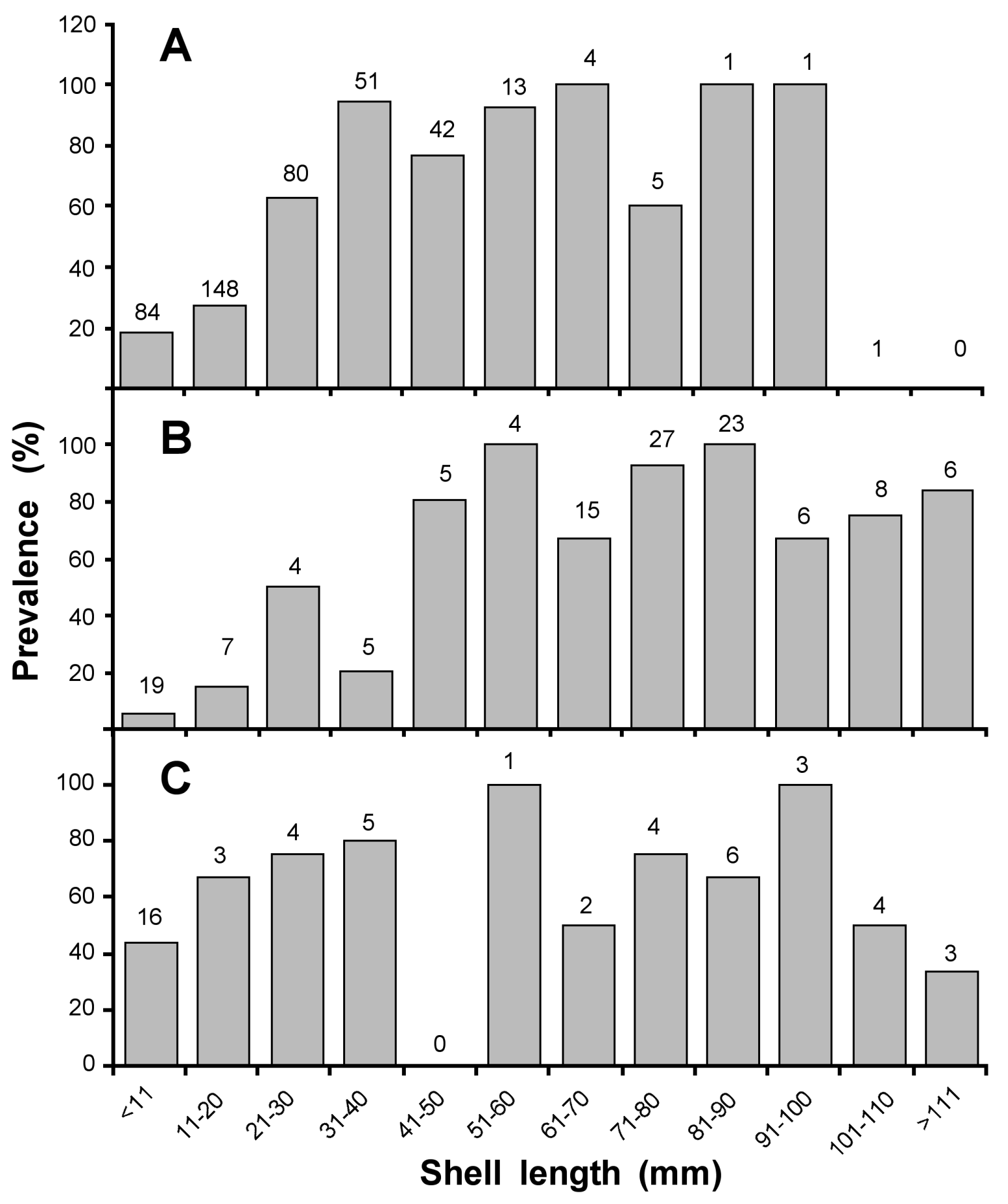

Fig. 2. Branchipolynoe seepensis and Bathymodiolus azoricus. Relationships between infestation rate and size. A. Lucky Strike 1995. B. Lucky Strike 2002. C. Rainbow 2002. Column labels indicate the number of mytilids. 


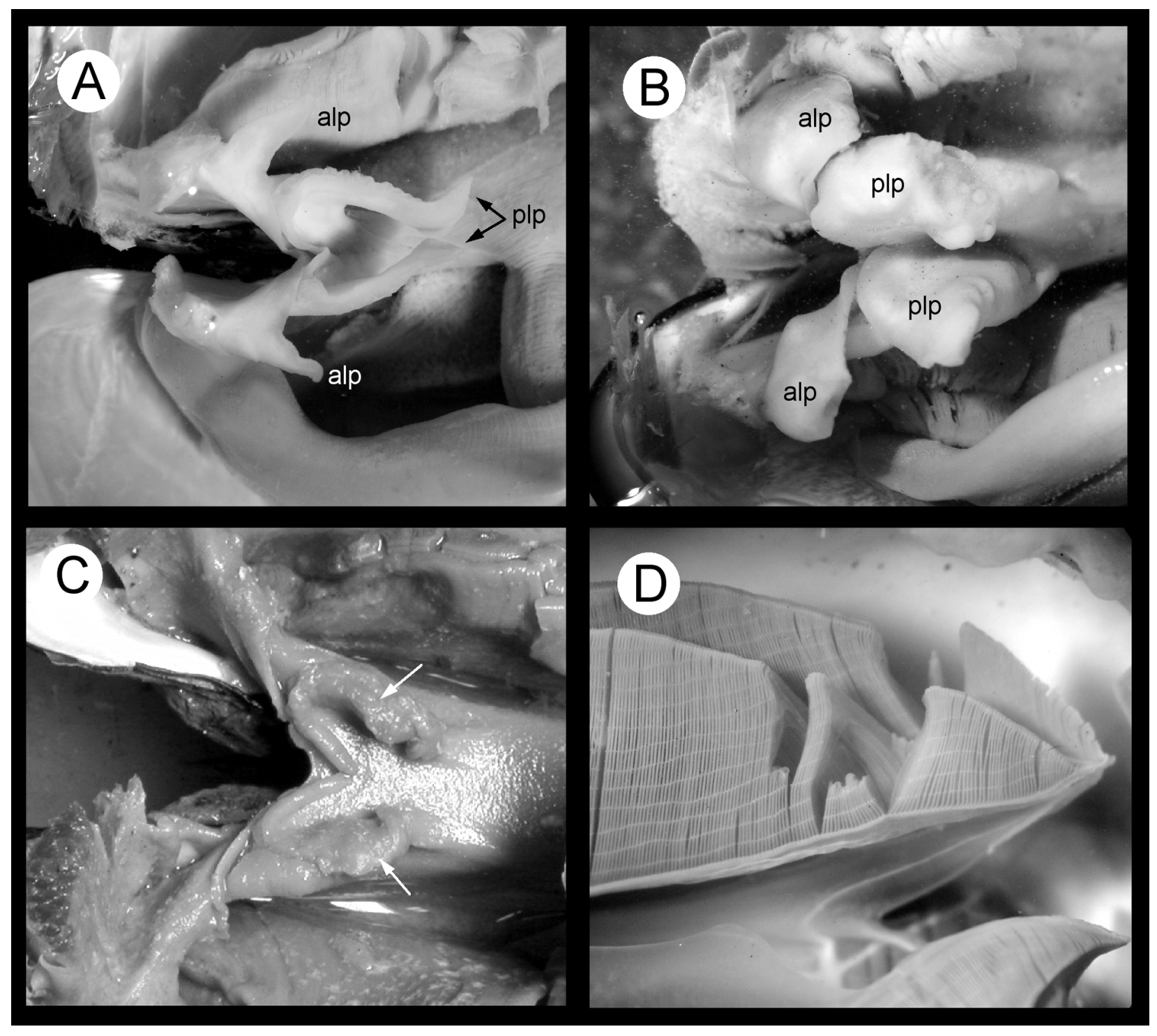

Fig. 3. Bathymodiolus azoricus. Light micrographs of trauma. A. Labial palps in intact state. B. Shortening of labial palps. C. Elimination of labial palps. D. Truncation of some groups of ctenidia. Alp: anterior palps; plp: posterior palps; white arrows: traces of palps. 

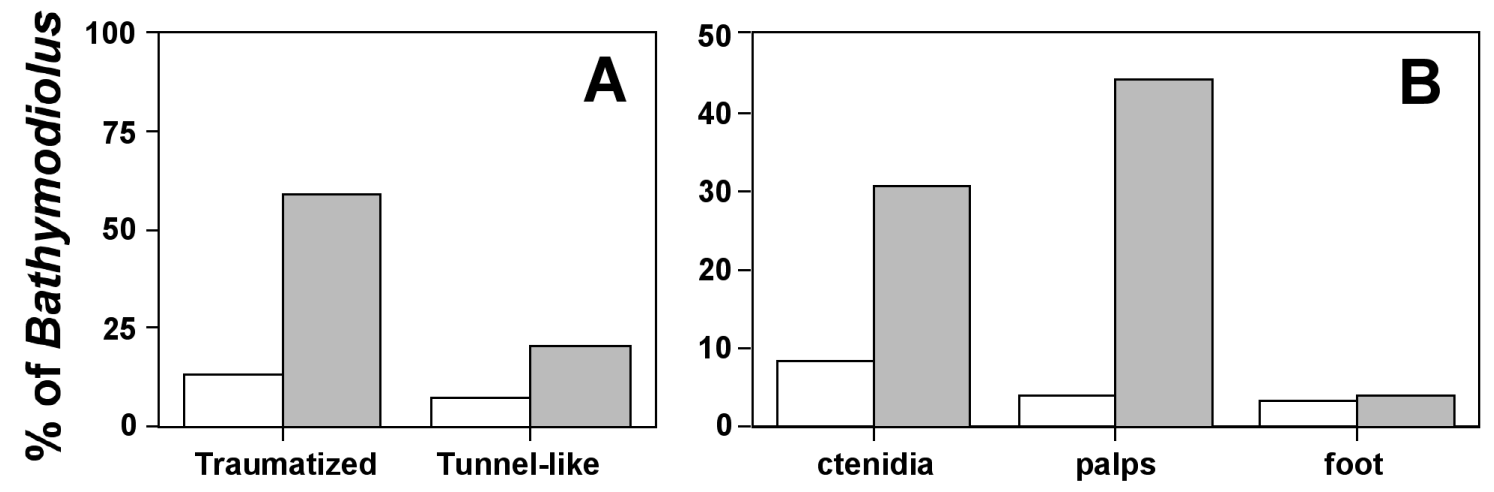

Non-infested ( $\mathrm{N}=248) \quad \square$ Infested $(\mathrm{N}=\mathbf{2 0 4})$

Fig. 4. Bathymodiolus azoricus. Presence of trauma in infested and non-infested specimens from Lucky Strike 1995.

A. Traumas and tunnel-like structures. B. Different types of trauma.
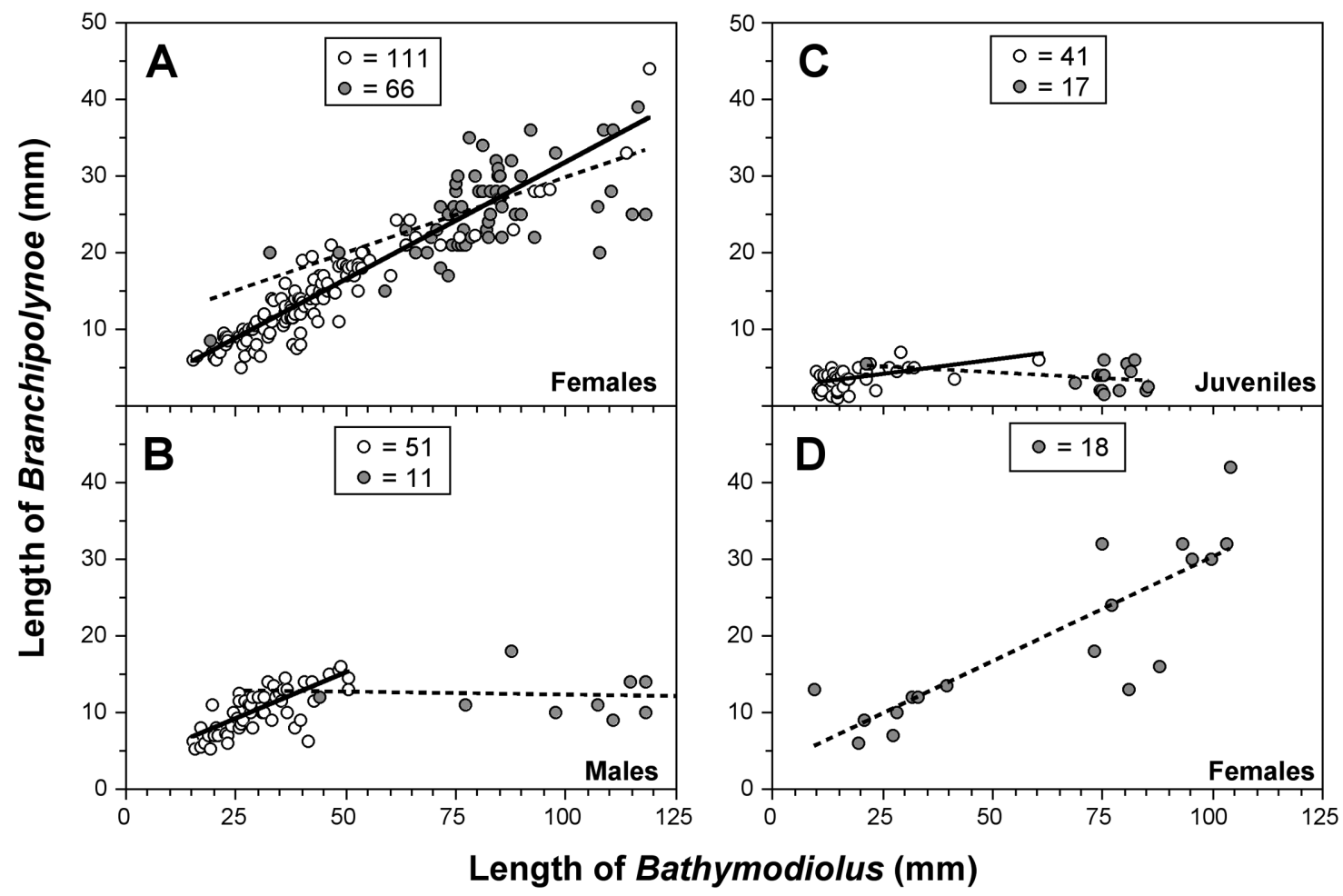

Length of Bathymodiolus (mm)

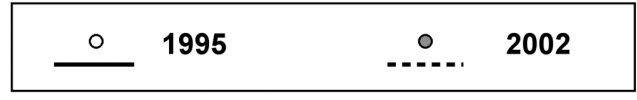

Fig. 5. Branchipolynoe seepensis and Bathymodiolus azoricus. Relationships between symbiont body length and host shell length. A-C. Lucky Strike. D. Rainbow. 


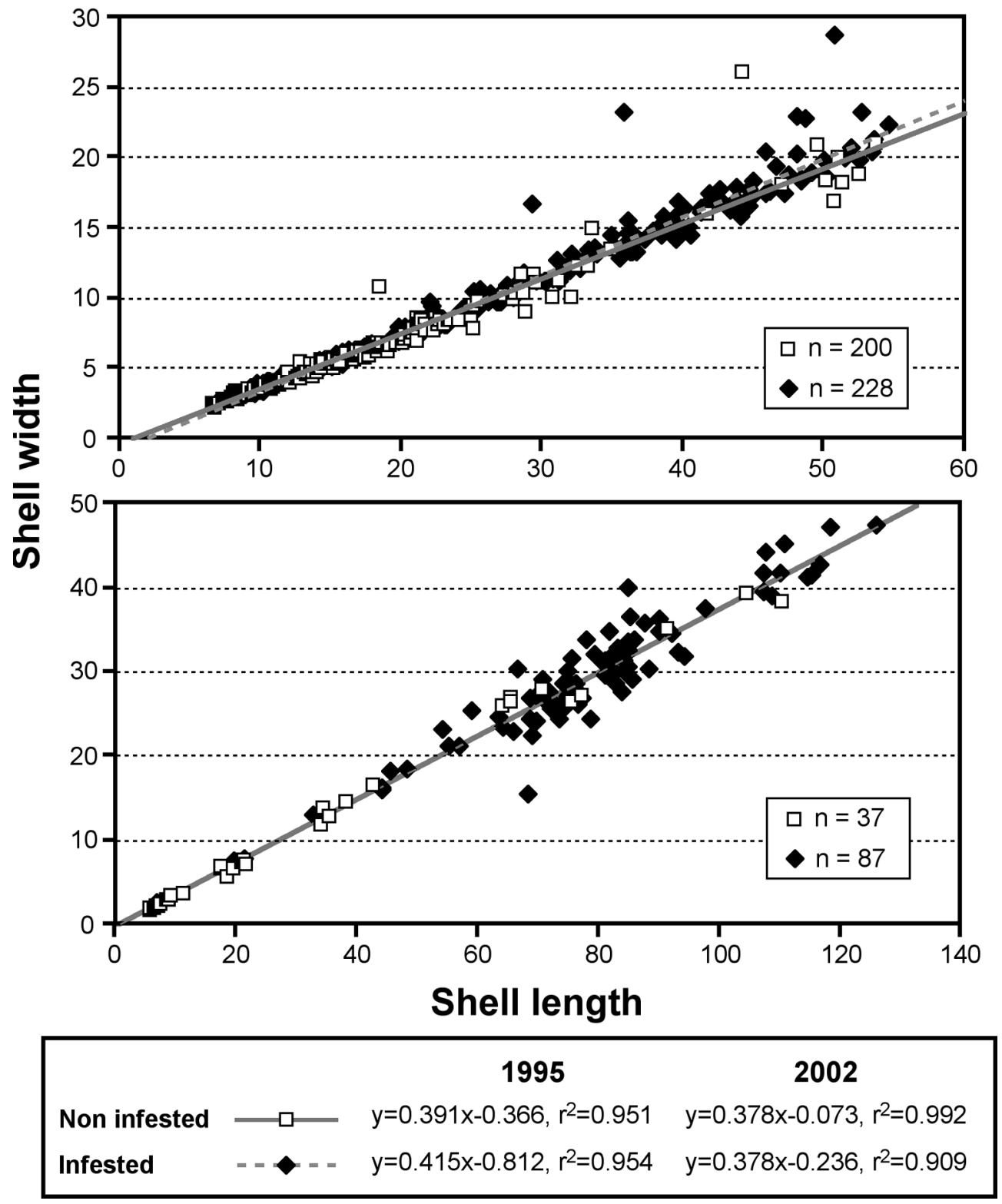

Fig. 6. Bathymodiolus azoricus. Length/width relationships in shells of infested and non-infested specimens. A. Lucky Strike 1995. B. Lucky Strike 2002. 


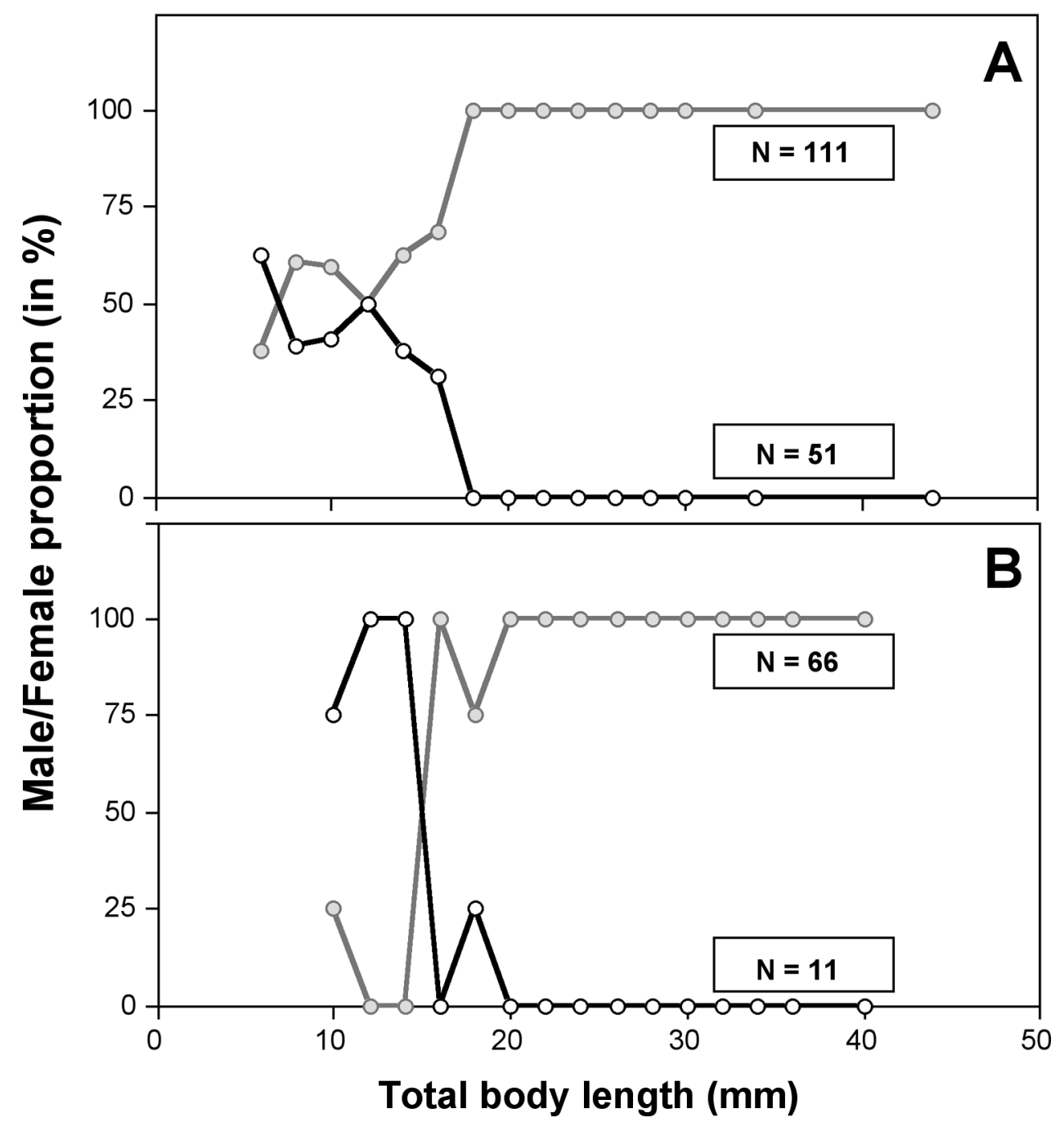

$\multimap$ males $\multimap-$ females

Fig. 7. Branchipolynoe seepensis. Sex structure. Changes in sex ratio according to symbiont size. A. Lucky Strike 1995. B. Lucky Strike 2002. 


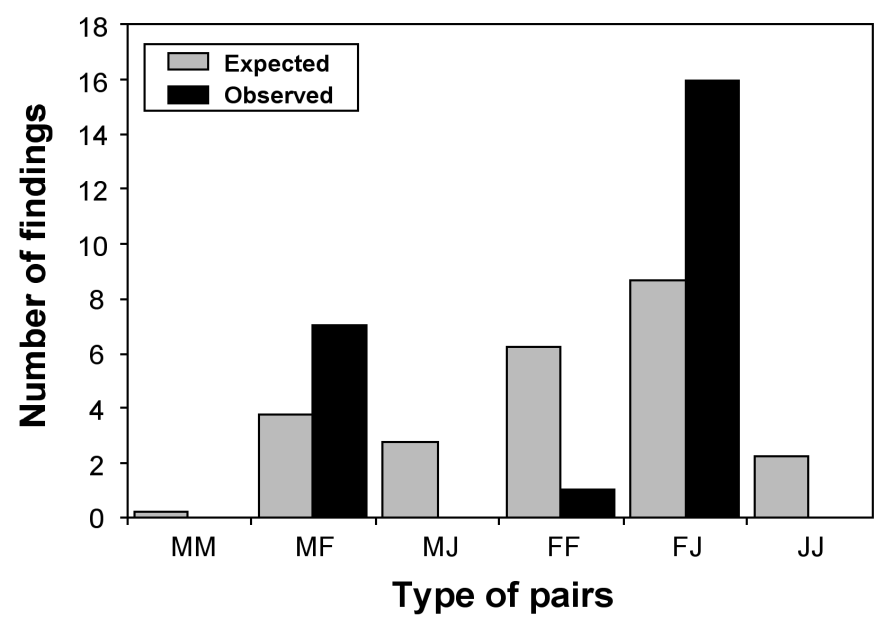

Fig. 8. Comparison between observed and randomly expected pairing in all available worms associated with Bathymodiolus azoricus. M: males. F: females. J: juveniles.

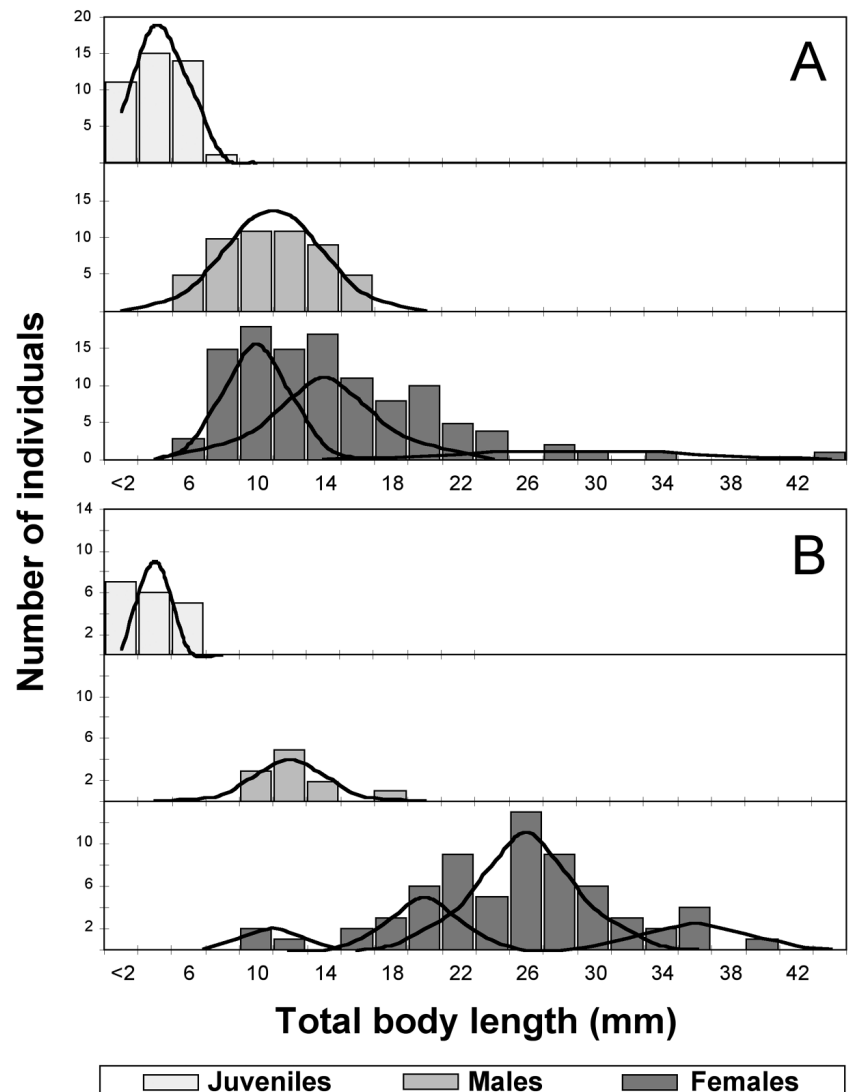

Fig. 9. Branchipolynoe seepensis. Size-frequency histograms of total length. A. Lucky Strike in $1995(\mathrm{~N}=205)$. B. Lucky Strike $2002(\mathrm{~N}=95)$. 


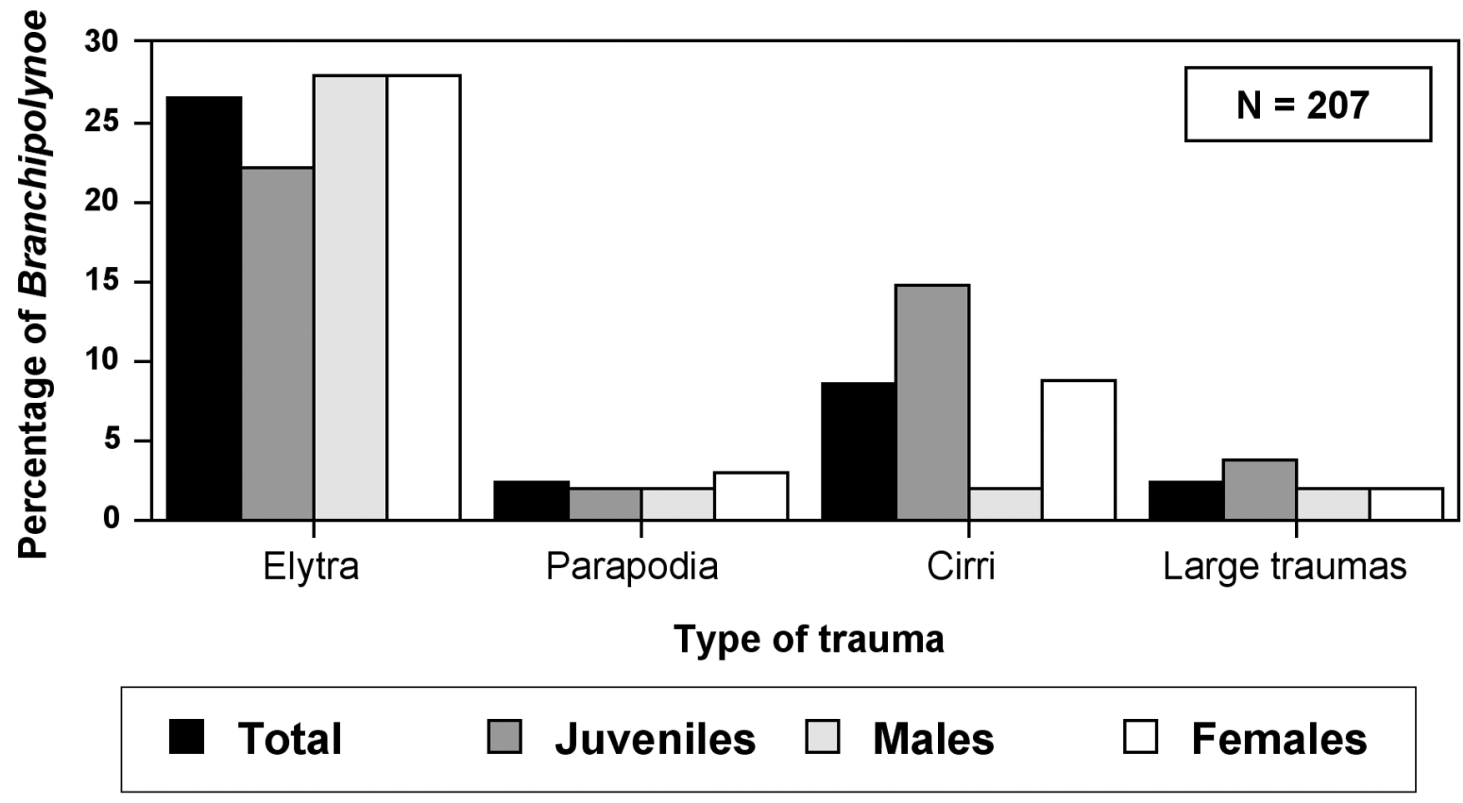

Fig. 10. Branchipolynoe seepensis. Frequency of trauma in Lucky Strike 1995 
Table 1. Branchipolynoe seepensis. Characteristics of the infestation of the two hydrothermal mytilid hosts Bathymodiolus puteoserpentis and Bathymodiolus azoricus. (n): number of hosts examined.

\begin{tabular}{llc}
\hline Locality & Prevalence (n) & $\begin{array}{c}\text { Abundance } \\
\text { (Intensity) }\end{array}$ \\
\hline Bathymodiolus puteoserpentis & & \\
\hline Logatchev, 1998 & $7.1 \%(182)$ & $0.07(0-1)$ \\
$\quad$ Snake Pit, 2002 & $23.3 \%(120)$ & $0.275(0-4)$ \\
\hline Bathymodiolus azoricus & & \\
\hline Rainbow, 1999 & $65.0 \%(20)$ & $0.70(0-2)$ \\
$\quad$ Rainbow, 2002 & $60.8 \%(51)$ & $0.80(0-3)$ \\
$\quad$ Lucky Strike, Statue de la Liberte, 1993 & $76.5 \%(34)$ & $0.73(0-1)$ \\
$\quad$ Lucky Strike, Elisabeth, 1995 & $54.8 \%(445)$ & $0.47(0-3)$ \\
Lucky Strike, 2002 & $71.3 \%(129)$ & $0.80(0-6)$ \\
\hline
\end{tabular}


Table 2. Distribution of Branchipolynoe seepensis by Bathymodiolus puteoserpentis and $B$. puteoserpentis hosts from different samples.

\begin{tabular}{lccccccc}
\hline Number of worms in one host & $\mathbf{0}$ & $\mathbf{1}$ & $\mathbf{2}$ & $\mathbf{3}$ & $\mathbf{4}$ & $\mathbf{5}$ & $\mathbf{6}$ \\
\hline Bathymodiolus puteoserpentis & & & & & & & \\
\hline Logatchev, 1998 & 169 & 13 & 0 & 0 & 0 & 0 & 0 \\
Snake Pit, 2002 & 92 & 27 & 0 & 0 & 1 & 0 & 0 \\
\hline Bathymodiolus azoricus & & & & & & & \\
\hline Rainbow, 2002 & 20 & 26 & 2 & 2 & 0 & 0 & 0 \\
Lucky Strike, Statue de la Liberte, 1993 & 4 & 34 & 0 & 0 & 0 & 0 & 0 \\
Lucky Strike, Elisabeth, 1995 & 244 & 194 & 6 & 1 & 0 & 0 & 0 \\
Lucky Strike, Sintra and Eiffel Tower, 2002 & 37 & 56 & 18 & 13 & 3 & 1 & 1 \\
\hline
\end{tabular}


Table 3. Branchipolynoe seepensis. Mean length (range) in $\mathrm{mm}$ of juveniles, males and females from different samples.

\begin{tabular}{lccc}
\hline Origin of the sample & Juveniles & Males & Females \\
\hline Lucky Strike 1995 & $3.3(1.0-7.0)$ & $10.3(4.3-16)$ & $13.6(6.0-33.0)$ \\
Lucky Strike 2002 & $3.5(1.5-6.0)$ & $11.2(9.0-18.0)$ & $24.9(8.5-39.0)$ \\
Rainbow 2002 & $4.3(2.0-7.0)$ & $13.3(8.5-17.0)$ & $19.5(6.0-42.0)$ \\
Mean length for all samples & $3.5(1.0-7.0)$ & $10.8(4.3-18)$ & $18.3(6.0-42.0)$ \\
\hline
\end{tabular}

